\title{
A Case of Scala Vestibuli Cochlear Implantation in Tympanogenic Labyrinthitis Ossificans
}

\author{
Yong-Soo Lee, Jae Hyung Heo, Yong-Ho Park, and Jin Woong Choi \\ Department of Otorhinolaryngology-Head and Neck Surgery, School of Medicine, Chungnam National University, Daejeon, Korea
}

\author{
만성중이염 후 골화된 와우에서 전정계를 통한 인공와우이식 1 예 \\ 이용수 · 허재형 · 박용호 · 최진웅 \\ 충남대학교 의과대학 이비인후-두경부외과학교실
}

\author{
Received November 24, 2016 \\ Revised January 5, 2017 \\ Accepted January 20, 2017 \\ Address for correspondence \\ Jin Woong Choi, MD, PhD \\ Department of Otorhinolaryngology- \\ Head and Neck Surgery, \\ School of Medicine, \\ Chungnam National University, \\ 282 Munhwa-ro, Jung-gu, \\ Daejeon 35015, Korea \\ Tel $+82-42-280-7694$ \\ Fax $+82-42-253-4059$ \\ E-mail choijw@cnu.ac.kr
}

Labyrinthitis ossificans (LO) is a pathologic formation of fibrosis and new bone within the lumen of the otic capsule. The LO is a challenging issue in cochlear implantation since obliteration and obstruction of the cochlea make electrode insertion through scala tympani (classic route) difficult. Moreover, tympanomastoidectomy for resolution of chronic otitis media is also simultaneously considered for tympanogenic LO with severe to profound hearing loss because ossification could progress in case of staged or delayed implantation after initial tympanomastoidectomy. We report a patient with tympanogenic LO, who received subtotal petrosectomy with simultaneous cochlear implantation via scala vestibuli instead of the scala tympani for hearing rehabilitation. Korean J Otorhinolaryngol-Head Neck Surg 2017;60(7):364-7

Key Words Chronic otitis media - Cochlear implantation · Labyrinthitis ossificans · Scala vestibuli $\cdot$ Subtotal petrosectomy.

\section{서 론}

와우골화(labyrinthitis ossificans)는 와우 내강이 섬유화 되고 골화되어 폐쇄되는 질환이다. 발생 원인으로는 세균성 뇌막염, 만성중이염, 진행된 이경화증, 자가면역질환, 측두골 (temporal bone) 골절 및 측두골 종양 등이 있다. ${ }^{1)}$ 이러한 다양 한 원인들에 의해 감염이 뇌막성(meningogenic), 고실성(tympanogenic) 및 혈행성(hematogenic), 내이로 전파되어 내이의 화농성 변화를 야기한다. 결국 이러한 내이염으로 인해 내이 조직은 섬유화 및 골화되어 폐쇄되며 감각세포들이 손상되어 난청이 발생한다. 고도 또는 심도이상의 난청이 발생하면 인공 와우를 통한 청각재활이 필요하다. ${ }^{2)}$

만성중이염에 의한 와우골화(tympanogenic labyrinthitis

This is an Open Access article distributed under the terms of the Creative Commons Attribution Non-Commercial License (http://creativecommons.org/licenses/by-nc/4.0) which permits unrestricted non-commercial use, distribution, and reproduction in any medium, provided the original work is properly cited.
Ossificans)는 만성중이염을 않고 이를 치료하기 위해 유양돌 기절제술을 시행 받은 환자의 약 $2 \%$ 정도에서 보고되어 세균 성 뇌막염에 의해 발생한 와우골화에 비해 드물다. ${ }^{3)}$ 와우골화 가 동반된 만성중이염에서 인공와우를 시행하는 경우 일차적 으로 유양돌기절제술 등을 통해 병변을 제거하고 수개월 후 인공와우를 시행하는 단계적 수술은 그사이 와우골화가 더 진행되어 전극이 불완전하게 삽입될 수 있는 위험을 증가시 킬 수 있다. 따라서 이러한 경우 중이염의 제거 및 인공와우를 동시에 시행하는 것이 모든 전극을 삽입할 수 있는 기회를 높 일 수 있다.

저자들은 만성중이염으로 와우 기저부에 골화가 진행된 성 인 환자에서 추체아전절제술(subtotal petrosectomy) 및 폐 쇄된 고실계(scala tympani) 대신에 전정계(scala vestibuli) 를 통해 인공와우 전극을 모두 삽입한 후 양호한 결과를 보 인 증례를 경험하였기에 문헌고찰과 함께 보고하는 바이다. 


\section{증 례}

64세 남자 환자가 4개월 전부터 악화된 청력소실을 주소로 내원하였다. 20여 년 전부터 양측의 중이염으로 간헐적으로 치료를 받았었다. 우측의 청력은 10 여 년 전부터 감소되기 시 작하였고 좌측은 5년 전부터 감소되기 시작하여 좌측 보청기 를 약 3년 전부터 착용하였고 최근 4개월 전부터는 보청기를 통해서도 듣기가 힘들었다. 신체검사에서 양측의 고막은 비후 되어 있었고 순음청력검사(pure tone audiometry)에서 양측 모 두 농이었다. 언어평가검사에서 categories of auditory performance(CAP)는 1 , 일음절단어검사(monosyllabic word test) 는 $0 \%$, 일상생활문장검사(common phrase test)는 $1 \%$ 였다. 측

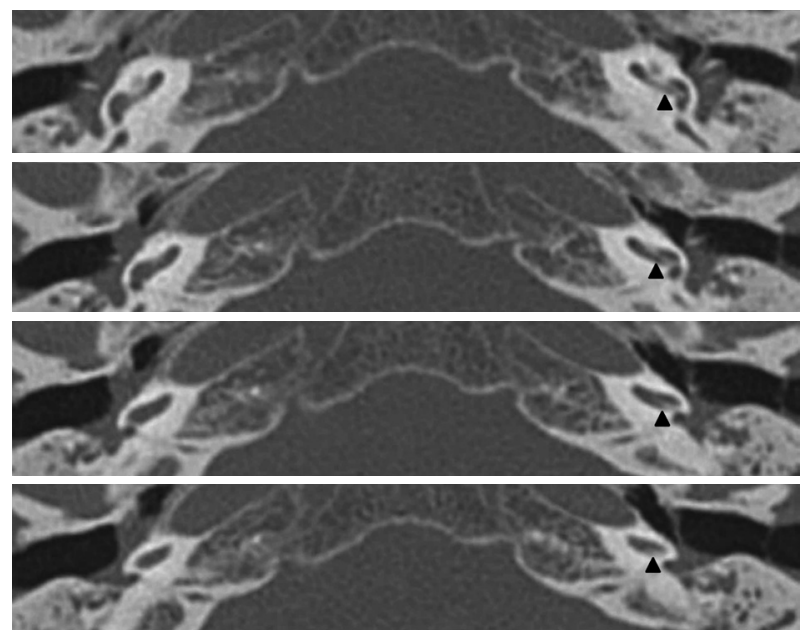

Fig. 1. Preoperative temporal bone computed tomography showing partial ossification in the basal turn of left side cochlea. Arrowhead indicates ossification of cochlea.
두골 단층영상검사에서는 양측의 유양돌기는 경화상 변화를 보였으며 중이 및 유양돌기에 연부조직 음영이 관찰되었다. 그리고 좌측 와우 기저부는 정상적으로 관찰되는 연부조직 음영이 일부 관찰되지 않고 골조직 음영이 관찰되었다(Fig. 1). 우측의 난청은 10 여 년 이상 되었고 최근까지 청각재활을 시 행한 쪽이 좌측이라 좌측의 추체아전절제술 및 인공와우 수 술을 결정하였다.

후이개 절개(retroauricular incision)를 통해 외이도 제거 및 이중폐쇄(double layer closure)를 시행하였으며, 외이도 피부, 고막 및 추골 등을 제거하고 유양돌기절제술을 시행하였다. 외이도는 안면신경관까지 낮추고 침골 등을 제거하였다. 유양 동(antrum)을 포함한 유양돌기 및 중이는 육아종 등의 염증 조직들로 차 있었다. 특히 등골 주위에는 심한 육아종성 변화 가 관찰되었다. 중이 및 유양돌기 등의 병변을 모두 제거한 후 (Fig. 2A) 정원창(round window)의 입구(lip)를 드릴을 이용 하여 구멍을 내어 정원창을 노출하였다. 그 후 정원창 전하방 역시 드릴을 이용하여 고실계를 노출하였다. 고실계는 섬유화 된 조직으로 폐쇄되어 있어 약 $4 \mathrm{~mm}$ 정도 섬유화된 부위를 따라 드릴을 이용하여 노출시키려 하였으나, 개방된 내강을 확인할 수 없었다. 내강을 찾기 위해 노출을 지속하는 경우 모 든 전극의 삽입이 어려울 수 있어 전정계의 상태를 확인해 보 기 위해 고실계의 상방을 노출시켰다. 전정계는 섬유화된 조 직이나 골화된 것 없이 잘 개방되어 있었다(Fig. 2B). 따라서 전 극을 전정계를 통해 삽입하였고 모든 전극을 삽입할 수 있었 다(Fig. 2C). 사용한 인공와우는 Nucleus CI422 Slim Straight (Cochlear Ltd., Sydney, Australia)였다. 이후 이관을 연부조 직 및 골편조직(bone pate)으로 폐쇄하고 복부지방을 이용하

Fig. 2. Intraoperative findings showing completion of exenteration of middle ear cleft (A), fibrosis of the scala tympani (B), full insertion of cochlear implant electrode through the scala vestibuli (C) and closure of musculoperiosteal flap with temporalis fascia (D). Black broken arrow indicates the opening of the scala vestibuli. Black arrow indicates the scala typmani obstructed by fibrosis and ossification. White arrow shows the marker indicating that electrode of cochlear implant was inserted fully.
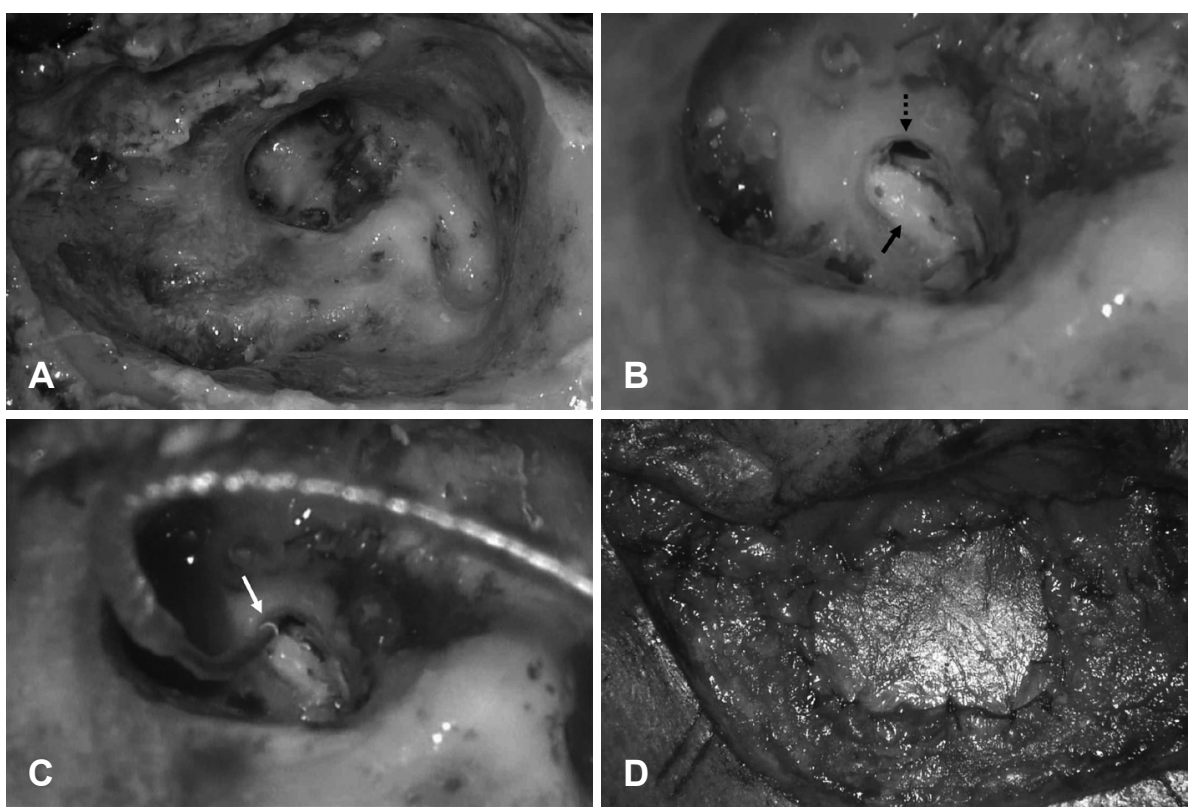
여 유양돌기강(mastoid cavity)을 폐쇄하였다. 미리 채취해 놓 은 측두근막을 이용하여 외이도 이중폐쇄로 인해 사용된 근 연골막 부위를 보강(Fig. 2D)하고 피부를 봉합하였다. 수술 중 시행한 신경반응 원격측정법검사의 모든 전극에서 정상적 인 파형이 관찰되었다. 수술 후 3일째 특이사항 없이 퇴원하 였고 수술 후 촬영한 측두골 단층영상에서 axial view 및 Poschel's view에서 전극이 전정계에 위치해 있는 것을 확인 할 수 있었다(Fig. 3). 수술 후 1, 3개월에 시행한 언어평가에서 각각 $\mathrm{CAP}$ 는 5,6 , 일음절단어는 $55.5,83.3 \%, 2$ 음절단어는
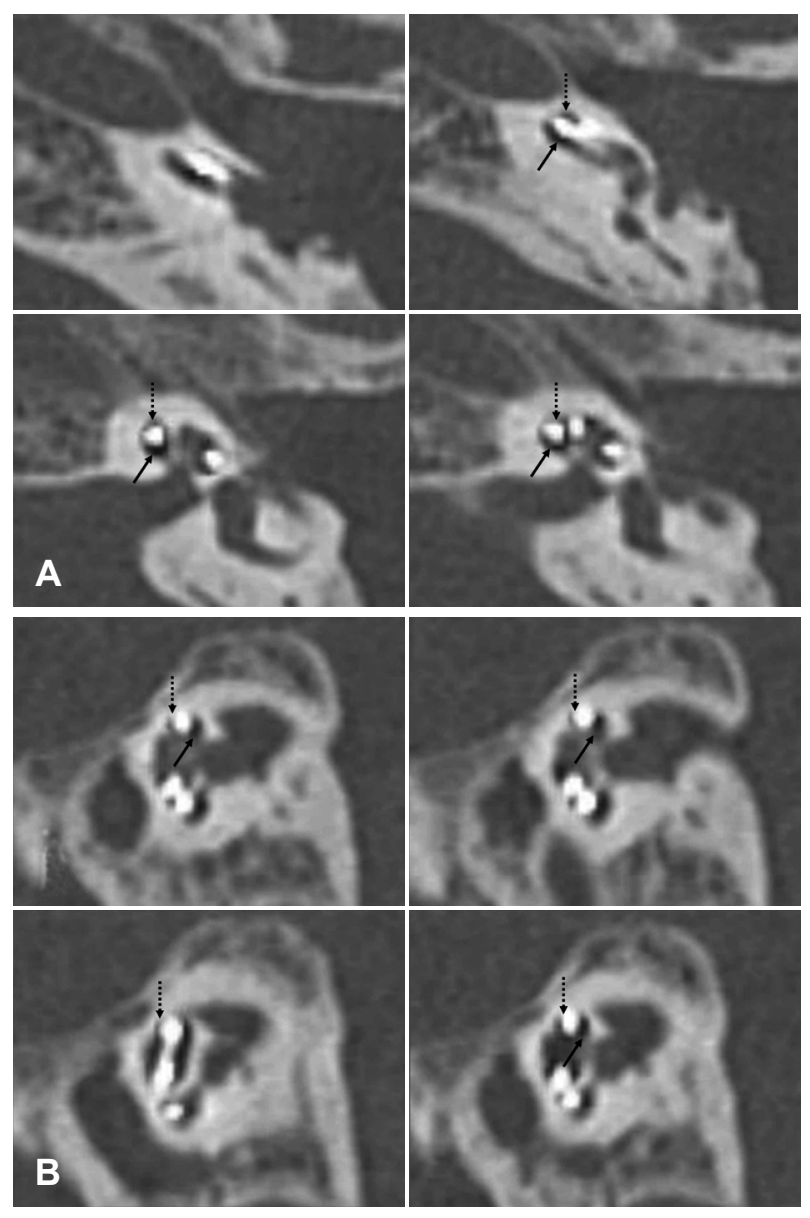

B

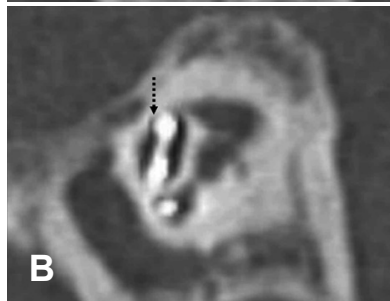

Fig. 3. Postoperative temporal bone computed tomography showing electrode of cochlear implant in the scala vestibuli (A: axial view, B: Poschel's view). Arrow and broken arrow indicates the scala tympani and the scala vestibuli, respectively.
$75,80 \%$, 일생생활문장검사는 79, 97\%였다(Table 1).

\section{고 찰}

고실계는 인공와우 수술 시 수술시야에서 접근성이 좋고 기 저막(basilar membrane)과 골성나선판(osseous spiral lamina) 에 의해 코르티기관(organ of Corti)과 같은 감각기관이 보호 되어 전극 삽입의 표준적인 경로로 이용된다. ${ }^{4-6)}$ 그러나 세균 성 뇌막염 또는 만성중이염과 같은 염증들이 내이로 전달되 는 경우 와우도수관이나 정원창 주위의 와우 기저부 고실계의 섬유화 및 골화를 유발하여 고실계를 폐쇄하여 전극의 삽입 이 힘들거나 불가능할 수 있다. 이러한 와우골화는 약 $90 \%$ 정 도가 정원창 주변부에만 국한된 병변으로 정원창 및 정원창 주변의 골화된 부위만 제거하면 고실계로의 전극 삽입이 가능 하다.) 반면에 약 $10 \%$ 정도에서는 골화 정도가 심하여 내경동 맥이 노출될 때까지 와우 기저부를 제거(drill-out)해야 전극 삽입이 가능하거나 폐쇄된 고실계 대신 전정계를 통해 전극을 삽입해야 한다. 골화된 부위가 기저부 전체 및 전정계를 포함 하는 경우에는 와우 중간부/첨부 개창술(middle or apical turn cochleostomy)을 통한 이중 전극(double array electrode) 등 을 삽입해야 한다. ${ }^{4}$

와우골화 정도가 심할수록 감각신경의 손상은 더 심하며, 수술 시 삽입될 수 있는 전극의 수도 적어, 인공와우 수술 후 결과에 나쁜 영향을 끼치므로 와우골화가 있는 경우 조기에 수술을 해야 한다. 특히 만성중이염으로 인한 와우골화인 경 우는 골화가 없는 만성중이염에서 인공와우를 시행하는 것 처럼 일차적으로 중이염을 제거한 후 이차적으로 인공와우 를 시행하는 것은 와우골화를 더 진행시켜 전극의 삽입을 어 렵게 할 수 있어 본 증례처럼 병변의 제거 및 인공와우를 동 시에 시행할 수 있는 추체아전절제술이 적합한 방법일 것으 로 사료된다.

전정계로의 전극 삽입은 삽입과정에 기저막 등의 손상 및 신경절 세포를 손상시킬 위험이 더 높고 신경절 손상으로 인해 와우 중간부 또는 첨부가 동시에 자극되는 교차자극(crossturn stimulation)을 야기할 수 있어 술 후 결과가 나쁠 수 있

Table 1. Preoperative and postoperative results of the speech test

\begin{tabular}{lcccc}
\hline \multicolumn{1}{c}{ Test } & Pre unaided & Pre aided & Post 1 mo & Post 1 mo \\
\hline Cap score & 0 & 1 & 5 & 6 \\
Open-set (\%) & & & 55.5 & 83.3 \\
Monosyllable words (AO) & 0 & 0 & 75 & 80 \\
Disyllable words (AO) & 0 & 0 & 79 & 97 \\
Sentence (AO) & 0 & 1 &
\end{tabular}


다. ${ }^{7)}$ 그러나 구조물의 손상이 발생하는 경우 고실계 삽입 중 전극이 전정계로 이탈이 되는 경우 발생하며 전정계 삽입을 처음부터 시도하는 경우에는 고실계 삽입과 비교하여 손상 의 차이가 없다고 보고되고 있다. 교차자극의 경우는 고실계 를 통해 삽입이 되었더라도 긴 전극이 와우 첨부(apical turn) 까지 도달한 경우 생길 수 있는 문제이다. ${ }^{8-10)}$ 따라서 전정계로 의 삽입자체가 술 후 결과에 나쁜 영향을 끼치는 것은 아닌 것 으로 생각된다.

와우골화 환자에서 전정계를 통한 전극 삽입은 Steenerson 등이이 처음 보고하였고 고실계를 통해 전극을 삽입한 환자 들과 동일한 결과를 보였다. 또한, 이 연구자들은 인체 측두골 연구를 통해 중간계(scala media)와 전정계를 합친 단면적과 고실계의 단면적이 유사하다는 것을 밝혀 본인들의 주장을 뒷받침하였다. ${ }^{11)}$ Adunka 등 ${ }^{10)}$ 도 인체 측두골 연구를 통해 전 정계를 통한 인공와우 수술은 라이스너 막(Reissner's membrane)은 손상되더라도 와우의 골성 구조들이나 감각신경구 조들에는 큰 손상을 일으키지 않는다고 보고하였다. 전극이 고실계에 위치한 경우와 전정계에 위치한 경우 영상의학적으 로 삽입된 깊이에 차이가 없으며 수술 후 전정기능에 미치는 영향도 차이가 없는 것으로 알려져 있다. ${ }^{12)}$

따라서 본 증례처럼 중이염에 의한 와우골화로 생긴 고도 이상의 난청 환자의 경우 가능한 조기에 추체아전절제술과 동 시에 인공와우 수술을 시행하여 와우폐쇄로 인한 불완전하 게 전극이 삽입될 수 있는 위험을 낮추어야 할 것으로 생각 되며, 고실계를 통한 전극 삽입이 불가능한 경우 폐쇄되어 있 지 않은 전정계를 통한 전극 삽입을 고려해 볼 수 있을 것으
로 생각된다.

\section{REFERENCES}

1) Eisenberg LS, Luxford WM, Becker TS, House WF. Electrical stimulation of the auditory system in children deafened by meningitis. Otolaryngol Head Neck Surg 1984;92(6):700-5.

2) Shelton MM, Marks WA. Bacterial meningitis: an update. Neurol Clin 1990;8(3):605-17.

3) Lin HY, Fan YK, Wu KC, Shu MT, Yang CC, Lin HC. The incidence of tympanogenic labyrinthitis ossificans. J Laryngol Otol 2014;128(7): 618-20.

4) Coelho DH, Roland JT Jr. Implanting obstructed and malformed cochleae. Otolaryngol Clin North Am 2012;45(1):91-110.

5) Kiefer J, Weber A, Pfennigdorff T, von Ilberg C. Scala vestibuli insertion in cochlear implantation: a valuable alternative for cases with obstructed scala tympani. ORL J Otorhinolaryngol Relat Spec 2000;62(5):251-6.

6) Steenerson RL, Gary LB, Wynens MS. Scala vestibuli cochlear implantation for labyrinthine ossification. Am J Otol 1990;11(5): 360-3.

7) Finley CC, Holden TA, Holden LK, Whiting BR, Chole RA, Neely GJ, et al. Role of electrode placement as a contributor to variability in cochlear implant outcomes. Otol Neurotol 2008;29(7):920-8.

8) Leake PA, Hradek GT, Snyder RL. Chronic electrical stimulation by a cochlear implant promotes survival of spiral ganglion neurons after neonatal deafness. J Comp Neurol 1999;412(4):543-62.

9) Shepherd RK, Hatsushika S, Clark GM. Electrical stimulation of the auditory nerve: the effect of electrode position on neural excitation. Hear Res 1993;66(1):108-20.

10) Adunka O, Kiefer J, Unkelbach MH, Radeloff A, Gstoettner W. Evaluating cochlear implant trauma to the scala vestibuli. Clin Otolaryngol 2005;30(2):121-7.

11) Gulya AJ, Steenerson RL. The scala vestibuli for cochlear implantation. An anatomic study. Arch Otolaryngol Head Neck Surg 1996;122(2): 130-2.

12) Nordfalk KF, Rasmussen K, Hopp E, Greisiger R, Jablonski GE. Scalar position in cochlear implant surgery and outcome in residual hearing and the vestibular system. Int J Audiol 2014;53(2);121-7. 